\title{
A systematic literature review on Engineering Entrepreneurship Education Learning Outcomes and Assessment Tools
}

\author{
Tate Ning. Cao, and Shaobo Huang \\ Ron and Jane Graham School of Professional Development \\ University of Saskatchewan \\ tate.cao@usask.ca,shaobo.huang@usask.ca
}

\begin{abstract}
Recent technological advancement is moving our society towards a more innovative and entrepreneurial one. As a result, engineering entrepreneurship education gained popularity and adoption across major education institutes worldwide. Based on a national survey done by Industry Canada, over $98 \%$ of Canadian post-secondary institutes offered at least one course in entrepreneurship. Despite this wide adoption, we believe the research on the short-term learning outcomes and assessment for engineering entrepreneur education on students is inadequate. This is often because of the lack of research in the engineering entrepreneurship and the lack of definition of engineering entrepreneurship education learning outcomes. We undertook a systematic review and metaanalysis of 123 studies on entrepreneurship education for undergraduate engineering students in North America in the past 15 years. We examined the learning outcomes defined and desired by major entrepreneurial educational institutes in North America and the assessment methods employed to measure the student learning outcomes. We particularly focused on the alignment between desired learning outcomes and assessment methods employed to study the validity and reliability of common assessment instruments.
\end{abstract}

In this paper, we report on the results of the systematic literature review, identify the strength of common assessment instruments, and then describe the process we incorporate what we learned from this review into our engineering entrepreneurship education program.

Keywords: Pedagogy in Engineering, Outcomes-Based Education, Experiential \& Hands-on Learning, Developing and Assessing Professional Skills, Engineering Design

\section{INTRODUCTION}

Engineering entrepreneurship education is a fast-growing area and interest within the education space. Entrepreneurship education is growing for many reasons.
Entrepreneurial engineers often solve difficult technical problems, drive local and global economic growth [1], and create net new jobs. Furthermore, entrepreneurship brings all aspects of business operations together and therefore develops a broad set of knowledge, skills and attitudes in students. Entrepreneurial engineers are often viewed as potential executive leaders in most organizations because of their broad understandings and abilities to solve complex problems. From the educators' perspectives, engineering entrepreneurship education also provides a unique offering to engineering students who may have an aptitude for business and entrepreneurship. The educators believe that academic courses and programs can inspire and equip engineering students with leadership, innovation and creativity, which are the essential concepts to become entrepreneurial engineers [2].

Despite of its popularity, engineering entrepreneurship education is a relatively new field. This is because the educators traditionally came from practitioners' background rather than academia. Therefore, little empirical research explores how students learn and how we can assess student learning outcomes. We believe there is a need to understand the current assessment methods and instruments as the universities are ramping up their entrepreneurship activities. A valid and reliable assessment method will ensure the quality and impact of an engineering entrepreneurship education program and enable educators to optimize their training programs. It is extremely important for us to understand the short term learning outcomes for educators to improve their program design and teaching delivery methods.

One of the challenges for developing a common assessment tool to evaluate the impact of entrepreneurship education for engineering students is the lack of a defined common body of knowledge. According to Fiet 2001[3], leading Henry, Hill, and Leitch (2005b) [4], the content developed by entrepreneurial teachers differed significantly from each other, "it is difficult to determine if they even have a common purpose." Since Shartrand et al. 
developed the NCIIA Entrepreneurship inventory [5] a few major conceptual frameworks have emerged for engineering entrepreneurship education. For example, the Kern Engineering Entrepreneurship Network (KEEN) developed a Three Cs model: Curiosity, Connections, and Creating Value [6]. This framework emphasizes entrepreneurial mindset and further defined associated educational outcomes shown in the figure below.

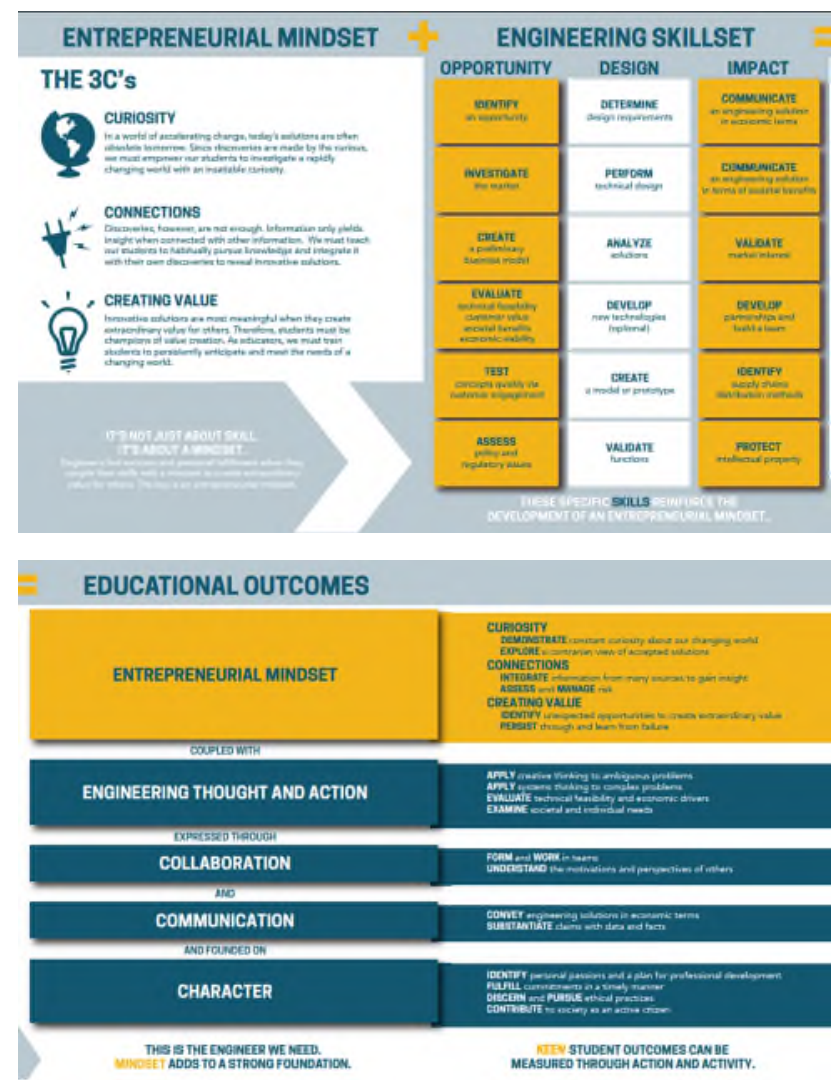

Figure 1 KEEN Entrepreneurial Mindset Framework [6]

The educational outcomes defined in the KEEN framework involve five dimensions: 1) Entrepreneurial mindset, 2) Engineering Through and Action, 3) Collaboration, 4) Communication, and 5) Character.

In the last two decades, there are more specific frameworks developed for technical entrepreneurship. One of the most notable ones is the Lean Launch Pad championed by Steve Blank and Eric Ries[7], [8]. The Lean Methodology is widely incorporated in technology entrepreneurship education programs, including the i-Corp program by National Science Foundation (NSF)[9]. The program focuses on the development of business skills for technical founders.

\section{Framework}

In the previous studies, the researchers attempted to establish a connection between a particular pedagogical intervention and certain changes in specific outcome variables. Such outcome measures need to align with the intended learning outcomes proposed in the engineering entrepreneurship courses or programs.

Longva et al. 2018 designed a framework based on Bloom and Kraiger's theory on learning [10] and classified entrepreneurial learning outcomes by cognitive, skillbased or affective capacities. The cognitive outcomes refer to knowledge about business basics and comprehension in entrepreneurship. The skill-based outcomes are linked to the essential skills for starting a business. The affective outcomes comprise the changes in attitudes and intentions, as well as the actions of pursuing entrepreneurship.

Based on the previous research, we decide to measure four categories of learning outcome measures in engineering entrepreneurship assessments as shown in Table 1. In our framework, we aim to measure students' desire for entrepreneurship (Why), their knowledge about the entrepreneurship (Can), their skills in conducting technical entrepreneurship (How), and their future behaviours after graduation regarding entrepreneurship (Will).

Table 1. Categories of outcome measures

\begin{tabular}{|l|l|l|}
\hline Framework & $\begin{array}{c}\text { Outcome } \\
\text { Measure }\end{array}$ & \multicolumn{1}{c|}{ Outcomes } \\
\hline Why & Affective & $\begin{array}{l}\text { Passion, motivation, self-efficacy, } \\
\text { opportunism, innovativeness, and } \\
\text { career options }\end{array}$ \\
\hline Can & Cognitive & $\begin{array}{l}\text { Knowledge: comprehension and } \\
\text { about entrepreneurship and basic } \\
\text { business knowledge, risk } \\
\text { assessment, creativity, decision } \\
\text { making, accounting, finance, sales } \\
\text { \& marketing, people human } \\
\text { resources, and pivot }\end{array}$ \\
\hline How & $\begin{array}{l}\text { Skills - } \\
\text { Business }\end{array}$ & $\begin{array}{l}\text { Business modeling, business } \\
\text { planning, business realization, } \\
\text { opportunity recognition, leadership, } \\
\text { product ideation, customer } \\
\text { discovery, and primary market } \\
\text { research }\end{array}$ \\
\cline { 2 - 4 } & $\begin{array}{l}\text { Skills - } \\
\text { Technical }\end{array}$ & $\begin{array}{l}\text { Design, teamwork, communication, } \\
\text { and professional practice }\end{array}$ \\
\hline Will & Behavioural & $\begin{array}{l}\text { Venture creation, employability, } \\
\text { and intentions }\end{array}$ \\
\hline
\end{tabular}

We also employed the Unified Theory of Validity framework developed by Messick (1995) to assess the degree of consistency between "empirical evidence and theoretical rationales support the adequacy and appropriateness of interpretations and actions based on test scores or other models of assessment. "[11]

\section{METHODOLOGY}

We performed a search of the literature for the current assessment methods in engineering entrepreneurship 
education. We then performed a mega content analysis on the current literature. The scope of the literature search focused on the North American Engineering Entrepreneurship Education in the last fifteen (15) years. Our search started by accessing three databases for peerreviewed publications on engineering education and entrepreneurship studies: Web of Science, Business Source Elite, and Emerald Insight. To cover the latest research on North American engineering entrepreneurship, we also searched the proceedings from the two major engineering education conference in Canada and the United States-- i.e. the Canadian Engineering Education Association (CEEA), and American Society for Engineering Education (ASEE).

The initial criterion is the inclusion of "engineering", "entrepreneurship", and any one of the following terms: "learning outcomes", "assessment", and "measure". This search resulted in 52 journal articles and 71 peer-reviewed conference proceedings. We then further screened the abstract of each paper by excluding any publications that did not describe the assessment instrument and the learning outcomes. At the end we identified 45 papers discussing 17 assessment instruments, their frameworks, learning outcomes measured, and the validity and reliability of the instruments.

\section{FINDINGS}

While entrepreneurship covers a range of different types of behavior, skills, and mindsets, we need to clarify the terminology to better understand the purposes and desired learning outcomes for engineering entrepreneurship education. The learning outcomes of engineering entrepreneurship education can range in four domains based on the publications we reviewed: Why, How, Can, and Will. This framework assesses students' mindsets, knowledge in entrepreneurship and business, skills in specific engineering discipline and business, and their entrepreneurial actions as a result of the education they received.

Through our research, we identified a few common frameworks for engineering entrepreneurship education and their desired learning outcomes. The KEEN three Cs' framework focuses on the development of the entrepreneurial mindset (EM). Its desired learning outcomes include the measures of EM (curiosity, connections, and creating value), and associated behaviors such as teamwork, communication, and system design [12].

Another widely adopted framework is the Lean launch Pad methodology developed by Steve blank that was used by NSF in i-Corp programs. The framework focusses on the knowledge and skills of an engineering entrepreneur including Customer Discovery, User Needs, Market Viability, MVP, Business Feasibility, and Technological Validity[13][8].
As for students' entrepreneurial actions, we found very limited studies in this area. This is consistent with the findings from a comprehensive survey of more than 500 engineering and technology companies conducted between 1995 and 2005 [14]. The results indicate that most students do not start a business immediately upon graduation. On average, the founders of these companies were 39 years old when they started their new ventures, and there were twice as many company founders who were 50 or older as those who were 25 or younger. This phenomenon significantly increased the difficulty of studying the long-term learning outcomes of entrepreneurship education. As a result there are very few research tools on the longitude alumni success with the exception of the survey tool for alumni research by Charles Easley [15]. The short-term learning outcomes are more measurable and can provide more meaningful feedback to the educators. The mostly used assessment is student self-assess survey, such as Entrepreneurial Intention, as a form of formative feedback. Other research methods such as concept mapping, course quizzes, and case studies are often used to provide summative feedback.

Many of the survey tools utilize students' self-assessed knowledge rather than a "direct measure of measurement of the actual skills and knowledge [16]". This approach would only capture the students' familiarity with concepts instead of their understandings of the concepts as well as their applications in real-life entrepreneurial situations.

In this review, we examined seventeen instruments that are frequently used for the assessment of entrepreneurial education. These assessment instruments covered a broad range of topics in engineering entrepreneurship. We then mapped the topics and learning outcomes with the framework we developed in Table 2.

Table 2 Entrepreneurship Learning Outcomes Assessed in Literature

\begin{tabular}{|l|l|r|}
\hline Framework & Outcome Measure & Number of Papers \\
\hline Why & Affective & 24 \\
\hline How & Cognitive & 13 \\
\hline Can & Skills - Business & 15 \\
\cline { 2 - 3 } & & Skills - Technical \\
\hline Will & Behavioural & 16 \\
\hline
\end{tabular}

These tools assessed the entrepreneurial mindset, cognitive understanding, technical and business skills, and entrepreneurial intention and behavior. A detailed list of survey tools is listed in Table 3. 


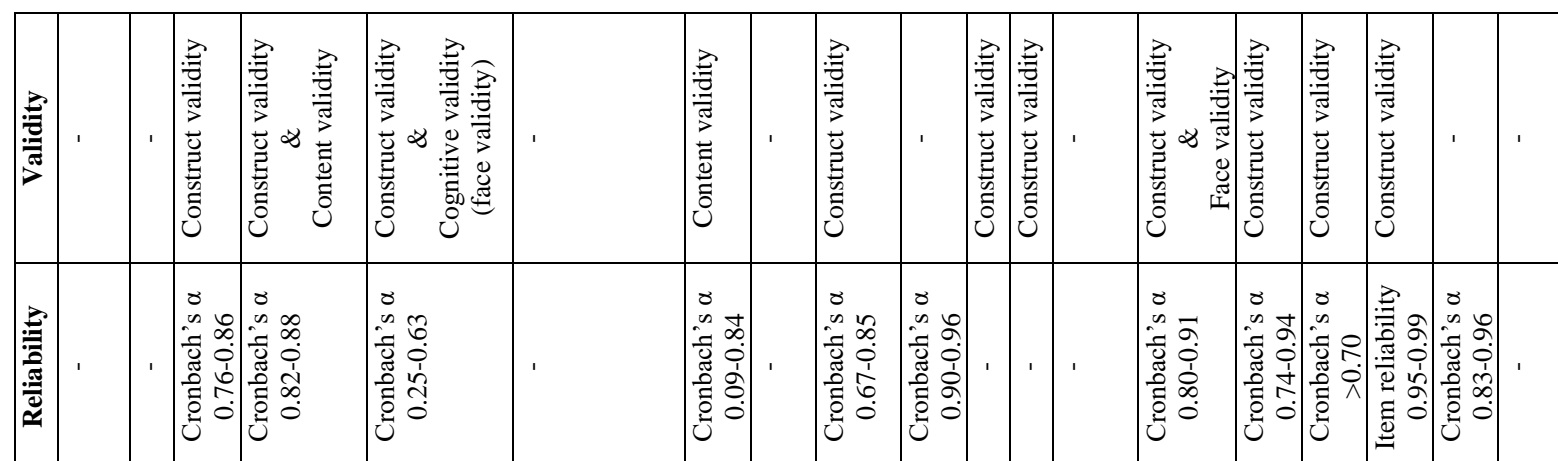

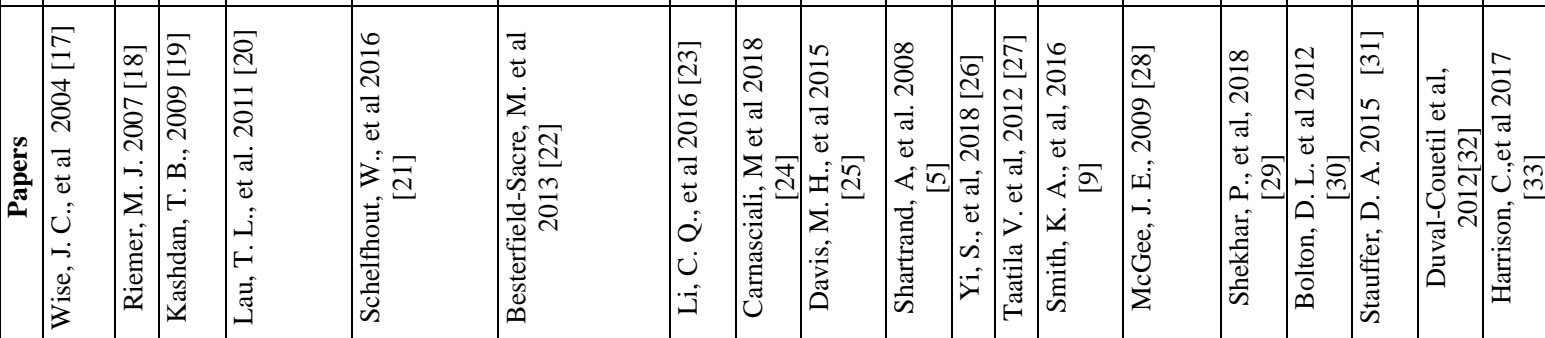

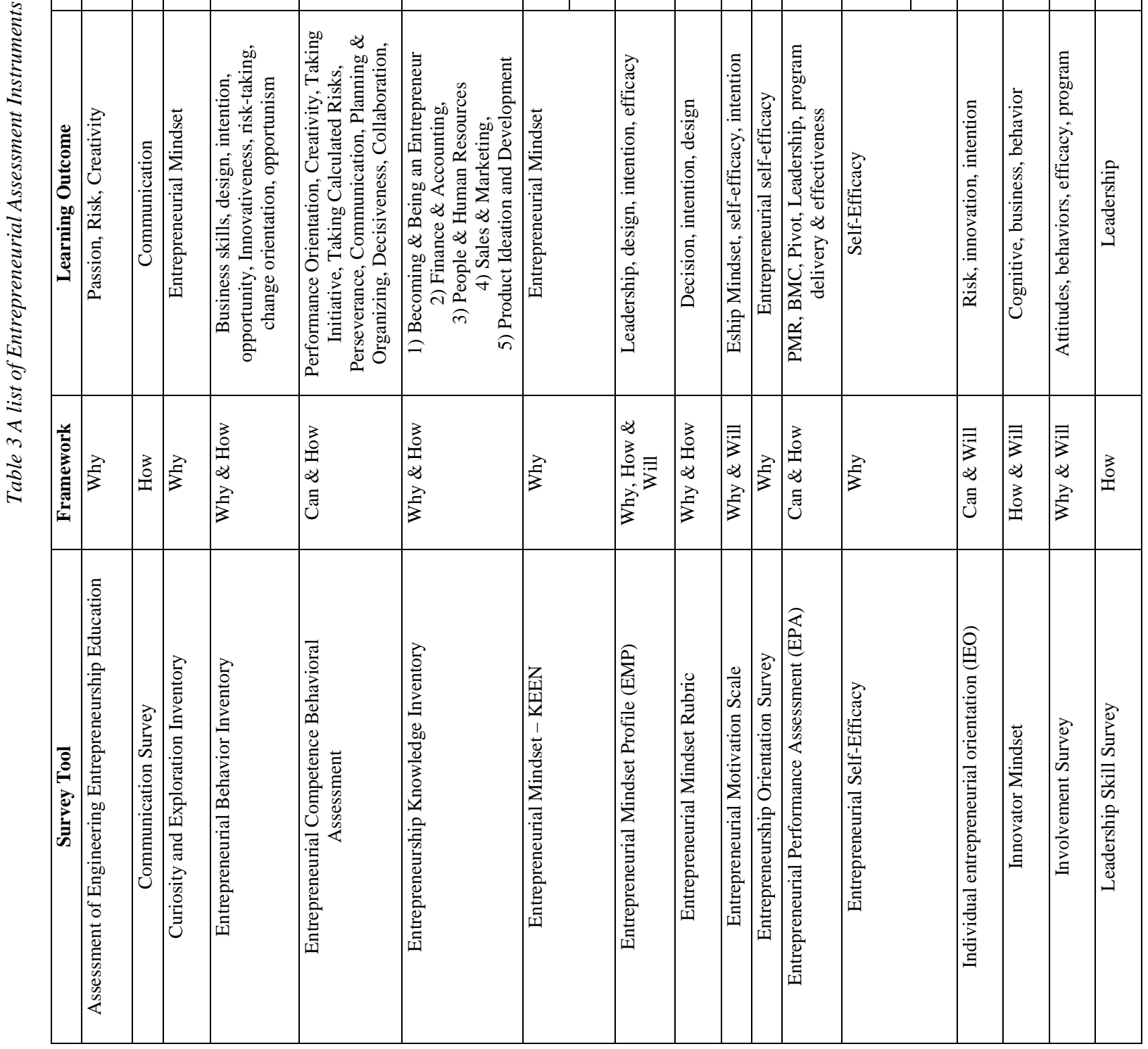


The instruments listed above were then examined for validity and reliability. Only 11 out of the 17 studies reported the direct evidence of reliability (Cronbach's alpha or Item reliability) for the assessment instruments and 8 of them achieved acceptable internal consistencies (Cronbach's alpha $>0.7$, or Item reliability $>0.8$ ) in all subscales. However, some instruments may have redundancy in the items as indicated by Cronbach's alphas greater than 0.9. Furthermore, the reliability of an assessment tool may change depending on the context in which it's used. For example, the Entrepreneurial Competence Behavioral Assessment demonstrated poor internal consistency when the context for the instrument changed [34].

Eleven (11) studies tested the validity of the resulting instruments while most of them focused on construct validity, i.e. whether an instrument measures specific entrepreneurial competencies, using confirmative factor analyses. Few studies investigated content validity, face validity, and criterion validity.

We also examined for the sample size and repeatability. We found that most of the assessment tools suffered from the lack of broad comparison and small sample sizes. This showed the needs for efforts to further validate these tools through empirical studies. Thirdly,

\section{DISCUSSION}

Our analysis of the literature on engineering entrepreneurship assessment resulted in two findings. Firstly, we found a broad range of engineering entrepreneurship assessment instruments for a variety of purposes, methods, and learning outcomes. However, few assessment instruments were designed to assess the course outcomes for the entrepreneurial curriculum and programs. Instead, the most commonly measured aspect for the entrepreneurial education was the entrepreneurial mindset (EM). Our analysis provides a framework to align the desired learning outcomes and appropriate assessment instruments.

Secondly, our analysis showed the quality of the assessment instruments varied. This is a result of the lack of evidence and verification of the validity and reliability of these instrument In addition, we identified the importance of defining the context for the entrepreneurship program before deploying an entrepreneurial assessment instrument. Given that many entrepreneurial assessment instruments were developed by researchers in business and management context, it is important to measure the professional and business related competencies that are unique for an entrepreneur from an engineering background. Furthermore, we also identified an alarming practice of modifying the survey instruments by combining multiple instruments into one single instrument without examining its validity[35][36]. Unfortunately, this common practice may alter the effectiveness of the assessment. More research are needed to validate the new instrument.

\section{CONCLUSION}

The engineering entrepreneurship education is still a field with developing theories. To achieve an effective and comparable assessment instrument, the institutions need to define a common objective and framework for their engineering entrepreneurship education. We found that the most of the researches focused on the frameworks such as Entrepreneurial Mindset (EM) as a theoretical framework for engineering entrepreneurship education learning outcomes. The focus on the mindset and skills is consistent with the role for university to teach people "how to fish" rather than to help students to "catch a fish". The focus poses two challenges. Firstly, the previous studies often used the survey tools to collect formative feedback for program evaluations. Little research focused on the pre/post-comparisons of the desired learning outcomes of the entrepreneurial courses, and therefore the result may subject to the selection bias where more entrepreneurial minded students may tend to take the entrepreneurship classes in the college of engineering. Secondly, the other challenge is the lack of research of how the students took actions as a result of their entrepreneurial education. While we do not believe the appropriate measure for entrepreneurial education programs in university should be venture creation, entrepreneurship is not a speculator sport. It is action focused. More research on how students apply their change of mindset in their volunteer activities, student projects, and even course work design may be beneficial.

We also recognize that a robust assessment tool needs to be able to accommodate the changes in education curriculum, because the entrepreneurship education changes rapidly. To achieve this, engineering educators are invited to utilize the assessment framework and instruments presented in this paper in their courses and programs. The broad evaluation and comparisons can further develop the literature for the engineering entrepreneurship assessment and help strengthen future work in understanding the adoptability and validity of current assessment instruments.

\section{Acknowledgements}

We wish to thank the Canadian Engineering Education Association's Board of Directors for supporting the formation of the Engineering Entrepreneurship and Technology Innovation Special Interest Group, along with all the colleagues who contributed to this work. 
[1] Ş. Purzer, N. Fila, and K. Nataraja, "Evaluation of current assessment methods in engineering entrepreneurship education," Adv. Eng. Educ., vol. 5, no. 1, pp. 1-27, 2016.

[2] S. P. Nichols and N. E. Armstrong, "Engineering entrepreneurship: Does entrepreneurship have a role in engineering education?," ASEE Annu. Conf. Proc., vol. 45, no. 1, pp. 4311-4320, 2001.

[3] J. O. Fiet, "The theoretical side of teaching entrepreneurship," J. Bus. Ventur., vol. 16, no. 1, pp. 1-24, Jan. 2001, doi: 10.1016/S08839026(99)00041-5.

[4] C. Henry, F. Hill, and C. Leitch, "Entrepreneurship education and training: Can entrepreneurship be taught? Part I," Educ. Train., vol. 47 , no. 2 , pp. $98-111$, 2005, doi: $10.1108 / 00400910510586524$.

[5] A. Shartrand, P. Weilerstein, M. BesterfieldSacre, and B. M. Olds, "Assessing student learning in technology entrepreneurship," Proc. Front. Educ. Conf. FIE, pp. 12-17, 2008, doi: 10.1109/FIE.2008.4720627.

[6] KEEN, "KEEN - The Framework." [Online]. Available: https://engineeringunleashed.com/mindsetmatters/framework.aspx. [Accessed: 19-May2020].

[7] S. Blank and B. Dorf, "The Startup Owner's Manual The Step-by-step Guide for Building a Great Company," Journal of Chemical Information and Modeling, 2013. [Online]. Available: https://books.google.ca/books?id=eSrfDwAAQB AJ\&printsec=frontcover\&dq=lean+launch+pad\& $\mathrm{hl}=\mathrm{en} \& \mathrm{sa}=\mathrm{X} \& \mathrm{ved}=0 \mathrm{ahUKEwjKoL}-$ Hp8DpAhVvRN8KHTVoCSoQ6AEIKDAA\#v=o nepage \&q=lean launch pad\&f=false. [Accessed: 19-May-2020].

[8] “The Lean Startup: How Today's Entrepreneurs Use Continuous Innovation to Create Radically Successful Businesses: Eric Ries: 9780307887894: Amazon.com: Books.” [Online]. Available: http://www.amazon.com/The-LeanStartup-EntrepreneursContinuous/dp/0307887898. [Accessed: 19-May2020].
[9] K. A. Smith, A. F. McKenna, R. C. C. Guerra, R. Korte, and C. Swan, "Innovation corps for learning (I-Corps ${ }^{\mathrm{TM}} \mathrm{L}$ ): Assessing the potential for sustainable scalability of educational innovations," in ASEE Annual Conference and Exposition, Conference Proceedings, 2016, vol. 2016-June, doi: 10.18260/p.25702.

[10] K. K. Longva and L. Foss, "Measuring impact through experimental design in entrepreneurship education: A literature review and research agenda," Ind. High. Educ., vol. 32, no. 6, pp. 358374, 2018, doi: 10.1177/0950422218804912.

[11] J. Menold, K. Jablokow, S. Zappe, P. Reeves, and L. Kisenwether, "Best Practices in Survey Development for Evaluation of Student Gains from Entrepreneurship Programs and Classes," Ventur. Open, no. 1997, pp. 1-10, 2015.

[12] L. Bosman, B. Mayer, and P. Mcnamara, "Promoting Entreprenuerially Minded Learning through Online Discussions Curriculum Innovation : Incorporating the Kern Engineering Entrepreneurial Network ( KEEN ) Framework into Online Discussions," in 2017 ASEE Annual Conference \& Exposition, 2017, pp. 1-12.

[13] A. A. Sipitanou and G. D. Papagiannis, "Education, Entrepreneurship and Entrepreneurial Activation: a Challenge for All," Int. J. Arts Sci., vol. 6, no. 2, pp. 139-149, 2013.

[14] V. Wadhwa, R. B. Freeman, and B. A. Rissing, "Education and Tech Entrepreneurship," 2011.

[15] C. E. Eesley, "Alumni Surveys as a Data Collection Methodology," SSRN Electron. J., Mar. 2018, doi: 10.2139/ssrn.3128628.

[16] M. Besterfield-Sacre, M. F. Cox, M. Borrego, K. Beddoes, and J. Zhu, "Changing engineering education: Views of U.S. faculty, chairs, and deans," J. Eng. Educ., vol. 103, no. 2, pp. 193219, Apr. 2014, doi: 10.1002/jee.20043.

[17] J. C. Wise and S. E. Rzasa, "Institutionalizing the assessment of engineering entrepreneurship," Proc. - Front. Educ. Conf. FIE, vol. 1, no. November 2004, 2004, doi: 10.1109/fie.2004.1408497. 
[18] J. D. Bakos, "Communication skills for the 21st century," J. Prof. Issues Eng. Educ. Pract., vol. 123, no. 1, pp. 14-16, 1997, doi: 10.1061/(ASCE)1052-3928(1997)123:1(14).

[19] T. B. Kashdan et al., "The curiosity and exploration inventory-II: Development, factor structure, and psychometrics," J. Res. Pers., vol. 43, no. 6, pp. 987-998, 2009, doi: 10.1016/j.jrp.2009.04.011.

[20] T. L. M. Lau, M. A. Shaffer, K. F. Chan, and T. W. Y. Man, "The entrepreneurial behaviour inventory: A simulated incident method to assess corporate entrepreneurship," Int. J. Entrep. Behav. Res., vol. 18, no. 6, pp. 673-696, 2012, doi: 10.1108/13552551211268120.

[21] W. Schelfhout, K. Bruggeman, and S. De Mayer, "Evaluation of entrepreneurial competence through scaled behavioural indicators: Validation of an instrument," Stud. Educ. Eval., vol. 51, pp. 29-41, Dec. 2016, doi: 10.1016/j.stueduc.2016.09.001.

[22] L. J. Shuman, M. E. Besterfield-Sacre, S. Streiner, G. Ragusa, C. Matherly, and L. Benson, "Assessing the spectrum of international undergraduate engineering educational experiences: A cross institutional survey," in ASEE Annual Conference and Exposition, Conference Proceedings, 2017, vol. 2017-June.

[23] C. Q. Li, R. S. Harichandran, M. I. Carnasciali, N. O. Erdil, and J. Nocito-Gobel, "Development of an instrument to measure the entrepreneurial mindset of engineering students," ASEE Annu. Conf. Expo. Conf. Proc., vol. 2016-June, 2016, doi: $10.18260 /$ p.26819.

[24] M. I. Carnasciali, R. S. Harichandran, N. O. Erdil, J. Nocito-Gobel, and C. Q. Li, "Integrated eLearning modules for developing an entrepreneurial mindset: Direct assessment of student learning," ASEE Annu. Conf. Expo. Conf. Proc., vol. 2018-June, 2018.

[25] M. H. Davis, J. A. Hall, and P. S. Mayer, "Developing a new measure of entrepreneurial mindset: Reliability, validity, and implications for practitioners," Consult. Psychol. J., vol. 68, no. 1, pp. 21-48, 2016, doi: 10.1037/cpb0000045.
[26] S. Yi and N. Duval-Couetil, "What Drives Engineering Students To Be Entrepreneurs? Evidence of Validity for an Entrepreneurial Motivation Scale," J. Eng. Educ., vol. 107, no. 2, pp. 291-317, 2018, doi: 10.1002/jee.20199.

[27] V. Taatila and S. Down, "Measuring entrepreneurial orientation of university students," Educ. Train., vol. 54, no. 8, pp. 744-760, 2012, doi: 10.1108/00400911211274864.

[28] J. E. Mcgee, M. Peterson, S. L. Mueller, and J. M. Sequeira, "Entrepreneurial self-efficacy: Refining the measure," Entrep. Theory Pract., vol. 33, no. 4, pp. 965-988, 2009, doi: 10.1111/j.15406520.2009.00304.x.

[29] P. Shekhar, A.-H. Saad, A. Ostrawoski, and A. Ostrawoski, "Promoting Innovation by Women through Engineering Entrepreneurship Courses: An Assessment of Entrepreneurial Self-Efficacy," Proc. Can. Eng. Educ. Assoc., Dec. 2018, doi: 10.24908/pceea.v0i0.12977.

[30] D. L. Bolton and M. D. Lane, "Individual entrepreneurial orientation: Development of a measurement instrument," Educ. Train., vol. 54, no. 2-3, pp. 219-233, 2012, doi:

$10.1108 / 00400911211210314$.

[31] D. A. Stauffer, "Evaluating mindset as a means of measuring personal innovativeness," Int. J. Innov. Sci., vol. 7, no. 4, pp. 233-248, Dec. 2015, doi: 10.1260/1757-2223.7.4.233.

[32] N. Duval-Couetil, T. Reed-Rhoads, and S. Haghighi, "Engineering students and entrepreneurship education: Involvement, attitudes and outcomes," Int. J. Eng. Educ., vol. 28, no. 2, pp. 425-435, 2012.

[33] C. Harrison, K. Burnard, and S. Paul, "Entrepreneurial leadership in a developing economy: a skill-based analysis," J. Small Bus. Enterp. Dev., vol. 25, no. 3, pp. 521-548, 2018, doi: 10.1108/JSBED-05-2017-0160.

[34] S. Mitchelmore and J. Rowley, "Entrepreneurial competencies: A literature review and development agenda," International Journal of Entrepreneurial Behaviour \& Research, vol. 16, no. 2. Emerald Group Publishing Limited, pp. 92 111, 09-Mar-2010, doi: 
$10.1108 / 13552551011026995$.

[35] M. D. Wilson, E. Holloway, and S. J. Gandhi, "Entrepreneurship Education: Engineering a Pracademic Approach,” 2018, doi: 10.17077/aseenmw2014.1038.

[36] E. Pluskwik, E. Leung, and A. Lillesve, "Growing entrepreneurial mindset in interdisciplinary student engineers: Experiences of a project-based engineering program," ASEE Anпи. Conf. Expo. Conf. Proc., vol. 2018-June, 2018. 